Carvalho, T. P. A.'; Cascardi, A. F.2.; Murolo, F. P.'; D'Oliveira, K. S. ${ }^{3}$
Martin, E. C': Merlo, A. ${ }^{2}$; Silva, P. T. D. ${ }^{3} ;$ Marcondes Santos, M. ${ }^{1}$; Chierichetti, A. L.4.; Ubukata, R. ${ }^{5}$; Fragata, F. S. ${ }^{6}$

\section{5 - Metástase ocular de tumor venéreo transmissível em cão. Relato de um caso}

1- Acadêmica de Medicina Veterinária da Universidade de Monte Serrat, Santos-SP

2- Médico Veterinário do Hospital Veterinário, Campus Jockey Club, São Vicente-SP

3- Professora de Cirurgia e Técnica Cirúrgica da Universidade de Monte Serrat, Santos-SP

O tumor venéreo transmissível (TVT) é neoplasia proliferativa cuja principal transmissão dá-se através do contato sexual. Ocorre na superfície mucosa da genitália externa de cães de ambos os sexos, porém pode também manifestar-se em outras áreas pelo contato direto, como: pele, mucosa anal, cavidade oral e nasal. Podem ser encontradas metástases em algumas regiōes, como tecido subcutâneo e raramente em globo ocular. $\mathrm{O}$ presente trabalho relata caso de TVT peniano com metástase ocular em cão sem raça definida, macho, de onze anos de idade e porte médio. $\mathrm{Na}$ anamnese, foi referido que o animal possuía contato com rua, errantemente. A queixa principal foi aumento de volume de globo ocular com protusão de massa intra-ocular há uma semana. No exame clínico observaram-se, à exposição peniana, múltiplos nódulos rígidos aderidos ao pênis, apresentando formatos irregulares, aspecto de couve - flor, ulcerados e medindo aproximadamente três centímetros de diâmetro cada. O cào apresentava ainda, em globo ocular esquerdo, blefarospasmo, congestão de vasos episclerais, buftalmia, leucoma corneano e neoformação em região axial da córnea, de formato irregular, coloração rósea e aproximadamente dois centímetros de diâmetro, drenando secreção sanguinolenta. Realizou-se imprint e punção aspirativa da massa ocular. Os materiais foram enviados a laboratório para análise citológica. Os valores hematológicos e bioquímicos se apresentaram dentro da normalidade. $\mathrm{O}$ laudo citológico revelou tumor de células redondas, e foi determinado diagnóstico presuntivo de TVT. Foi administrada quimioterapia com sulfato de vincristina $\left(0,5 \mathrm{mg} / \mathrm{m}^{2}\right)$, em intervalo semanal. Logo após a primeira dose, ocorreu regressão significativa de ambas as massas apresentadas, e houve supressão de qualquer tipo de secreçào da neoplasia ocular, a qual apresentou aspecto mais ressecado. $\mathrm{O}$ animal recebeu apenas duas doses da droga quimioterápica, devido à opção do proprietário pela interrupção do tratamento. Através da observação dos aspectos clínicos e do diagnóstico terapêutico, com regressão rápida das neoplasias frente ao tratamento implantado, confirmou-se a ocorrência de TVT peniano com metástase ocular, situaçào rara e pouco citada em literaturas.

\section{6 - Múltiplos sarcomas atípicos recidivantes em um felino. Relato de caso}

1- Departamento de Clínica Médica do Hospital Veterinário Sena Madureira, São Paulo-SP

2- Departamento de Clínica Médica e Diretor de internação do Hospital Veterinário Sena Madureira, São Paulo-SP

3- Departamento de Anátomo - patológico do Hospital Veterinário Sena Madureira, São Paulo-SP

4- Departamento de Cirurgia do Hospital Veterinário Sena Madureira, São Paulo-SP

5- Departamento de Oncologia do Hospital Veterinário Sena Madureira, São Paulo-SP

6- Departamento de Anestesiologia do Hospital Veterinário Sena Madureira, São Paulo-SP

Sarcomas sào as neoplasias mesenquimais malignas mais comuns em gatos, representando 12 a $25 \%$ de todos os tumores de pele e subcutâneo. Sarcomas felinos podem estar associados ao vírus do sarcoma felino e a reaçòes adversas a vários tipos de vacina $\mathrm{e}$ medicamentos. Tumores múltiplos causados pelo vírus do sarcoma felino acometem gatos jovens infectados também pelo virus da leucemia felina. Sarcomas não associados a vírus decorrem em maior frequêencia da aplicação de vacinas e medicamentos, sendo tipicamente solitários e de localização subcutânea. Os sarcomas vacinais demonstram crescimento rápido e infiltrativo e recidivam localmente em até $70 \%$ dos casos em seguida a exérese. 
Um felino macho, sem raça definida, de 6 anos, foi atendido no Hospital Veterinário Sena Madureira 2 dias após biópsia excisional, em colega, de 5 tumores subcutâneos em abdômen ventral. Somente um dos tumores havia sido encaminhado para histopatologia, tratando-se de um fibroma. Decorridos 30 dias de admissão ao hospital, observaram-se formaçōes em região de mamas torácicas a inguinais, que foram excisadas no $51^{\circ}$ dia de atendimento. Pelo exame histopatológico, houve 5 neoplasmas distintos: mixoma, mixossarcoma, fibroma, fibrossarcoma e mastocitoma bem diferenciados. Ocorreu recidiva em vários pontos de pele e mamas, motivando outra cirurgia no $90^{\circ}$ dia. A análise histopatológica das 4 formações retiradas acusou um tipo neoplásico semelhante, caracterizado por proliferaçào mesenquimal de células alongadas com moderado grau de anaplasia, embebidas em estroma frouxo mixomatoso com limites imprecisos. Tal proliferação mostrou-se associada ora a reação piogranulomatosa por fio de sutura, ora a infiltrado inflamatório misto com presença de neutrófilos, macrófagos, linfócitos e grande quantidade de mastócitos, sem sinais de invasão de camadas profundas. Com 140 dias de atendimento, o animal veio a óbito com metástases em pele abdominal (quatro), narinas, olhos e ânus, sem que necrópsia fosse realizada por decisão do proprietário. Os procedimentos cirúrgicos no hospital foram precedidos de exames de imagem (radiografia torácica e ultra-sonografia abdominal) que não apontaram metástases. Pesquisando informações de literatura, o presente caso revela-se atípico, pois trata de sarcomas múltiplos claramente nào-infiltrativos e acompanhados de processo inflamatório marcante, em um paciente de meia idade. Essa modalidade de sarcoma, clinicamente e histologicamente incomum, pode guardar semelhança com certo tipo de fibrossarcoma inflamatório humano, com aspecto de pseudotumor, de ocorrência em mesentério e retroperitôneo.

\section{7 - Osteossarcoma de patela em cão. Relato de caso}

Selmi, A.L. ${ }^{2}$; Nishiya, A.T. ${ }^{\dagger}$; Moreira, M.A.B.'; Moura, C.A. ${ }^{2}$; Provasi, A. ${ }^{2}$; Eimantas, G.C. ${ }^{2}$; Coelho, H.C.C. ${ }^{3}$; Guerra J.L. ${ }^{4}$
1- Hospital Veterinário Universidade Anhembi-Morumbi, São Paulo-SP

2- Faculdade de Medicina Veterinária da Universidade Anhembi-Morumbi, São Paulo-SP

3- Graduação da Faculdade de Medicina Veterinária Universidade Anhembi-Morumbi, São Paulo-SP

4- Supervisor da Faculdade de Medicina Veterinária da Universidade Anhembi-Morumbi, São Paulo-SP; Departamento de Patologia da Faculdade de Medicina Veterinária e Zootecnia da Universidade de São Paulo, São Paulo-SP

Os osteossarcomas são os tumores ósseos primários mais freqüentes em cães $(85 \%)$. Acometem, na maioria das vezes, animais de médio a grande porte com idade média de 7 anos. $75 \%$ ocorrem no esqueleto apendicular, principalmente nas regiões metafisárias distais de rádio e proximal de úmero. Os osteossarcomas de patela são pouco freqüentes. Foi atendido no Hospital Veterinário da Universidade Anhembi Morumbi, um animal da espécie canina, fêmea, sem raça definida de 10 anos de idade com histórico de claudicaçào de membro pélvico esquerdo há 45 dias. No exame fisico, observou-se discreto aumento de volume em região patelar esquerda, consistência firme e discreta sensibilidade. $\mathrm{O}$ exame radiográfico (articulaçào fêmoro-tibio-patelar e tórax) evidenciou -se área circular de osteólise nas regiōes média e distal de patela esquerda, com proliferação óssea de aspecto irregular e heterogêneo na sua margem dorsal. Observou-se, também, irregularidade de contorno ósseo. Ao exame radiográfico de tórax não foram encontradas evidências sugestivas de metástases. Realizaram-se exames pré-anestésicos de hemograma, dosagem sérica de creatinina , uréia e eletrocardiograma, que nào contra-indicaram o procedimento cirúrgico. $\mathrm{O}$ animal foi, então, submetido à artrotomia parapatelar medial e patelectomia esquerda. Foi realizado um reforço do tendào patelar com retalho pediculado de fáscia lata. No exame histopatológico, verificou-se tecido ósseo neoformado, aleatoriamente distribuído com osteoblastos proliferados, denotando alto grau de anaplasia, com inúmeras figuras atípicas de mitoses, caracterizando um osteossarcoma patelar. No $7^{?}$ dia pós cirúrgico, o animal apresentava bom estado geral e apoio do membro pélvico esquerdo ao passo e em estaçào. 